\title{
Review of Educational Psychology: Attitudes towards Physics
}

\author{
Astalini, Darmaji, Dwi Agus Kurniawan*, Tari Okta Puspitasari, Artha Lumbantoruan, \\ Yolanda Eka Putri, Nirmala Sari
}

Faculty of Teaching and Education, Universitas Jambi, Indonesia

Received December 23, 2019; Revised January 21, 2020; Accepted February 28, 2020

Copyright $\odot 2020$ by authors, all rights reserved. Authors agree that this article remains permanently open access under the terms of the Creative Commons Attribution License 4.0 International License

\begin{abstract}
The purpose of this research is to find out the comparis on of students' attitudes towards physics and the results of the student attitudes description by using indicators of scientist normality, scientific attitudes adoption and a career interest in physics at SMA Ferdy Ferry Putra Kota Jambi and SMAN 6 Batang Hari. This type of research is quantitative using survey research procedures where the instruments used are questionnaires. The subjects of this study were 281 students consisting of 125 students from SMA Ferdy Ferry Putra Kota Jambi and 156 students from SMAN 6 Batang Hari. Quantitative data analysis techniques use descriptive and inferential statistics. The results are indicator of the scientis ts normality towards physics which has differences in each school, which amounted to $65.6 \%$ and $44.9 \%$ with sufficient and good categories. For the indicator of the most dominant scientific attitudes adoption is categorized as good with a percentage of $62.4 \%$ and $64.1 \%$, respectively. Then the indicators of career interest in physics also have similarities in each school, namely sufficient categories with a percentage of $68 \%$ and $66 \%$. Based on these results, students at SMA Ferdy Ferry Putra Kota Jambi have sufficient attitudes towards learning physics. While at SMAN 6 Batang Hari students have good attitudes towards learning physics.
\end{abstract}

Keywords Attitudes, Physics, Student, Comparis on

\section{Introduction}

Education is an effort made to grow and develop the potential of human resources, especially students by guiding and facilitating their learning activities. Education plays an important role in improving the quality of human life [1]; [2]. One level of education that has high quality and high competitiveness human resources is the Senior
High School. As for the education in Indonesia, there are several levels. One of them is Senior High School level. Senior High school is an educational institution that organizes learning, teaching activities, receives and gives lessons according to levels, majors and so on, which have supporting elements such as facilities, infrastructure and according to applicable rules with the function to provide teaching for students so that they become individuals which is useful for himself and his environment [3]. This goal can be achieved if supported by several influencing factors such as the quality of teaching, the teaching methods used, teaching materials used, preparation of materials, and curriculum used. Achieving the potential of education can be obtained through an educational institution, one of them is Senior High School. At these levels students have begun to gradually be able to control themselves in thin king scientifically. As a development of the students mindset, the related subjects are Physics.

The ability of logic and basic calculations in mathematics is needed in learning physics so that understanding from the initial material to the final material can connect to one another [4]. Meanwhile according to, [5] physics subjects are considered important to be taught as subjects because physics is a vehicle to grow thinking skills that are useful for solving problems in daily life and equip students with knowledge, understanding and a number of abilities that constitute requirements for entering a higher level of education. In fact, physics is one of the subjects that is considered heavy and is avoided by some students because it requires perseverance, thoroughness and lots of practice [2]. One of the basic weaknesses is the low ability to think analytically about a problem. The success of teaching and learning activities in physics learning can be measured by the success of students who take part in learning activities [6]. One of the low physics learning results is due to the tendency of lecturers to place more emphasis on mathematical aspects so that innovation is 
needed in lectures. Psychology is one of the related sciences with human attitudes [7]. Psychology is a discipline on cognition and mental process that become the basis of human behavior. It has some subdisciplines such as memory, learning, perception, and problem-solving [7].

Attitudes related to coping with emotions that occur during the learning process take place, and they play an important role in shaping human behavior [10-13]. Because positive attitudes of students towards lessons are needed to determine their focus on lessons and students who have negative attitudes will also affect their learning outcomes [14]; [15]. Therefore, students who have a positive attitude in learning will influence or improve the learning outcomes of these students. The effect of the being scientific based character education program on gaining necessary knowledge, attitude and behaviors was positive [16]; [17].

Scientist normality is someone who looks ordinary and is the same as ordinary people. A scientist is often portrayed in the media. Students describe scientists as bearded / bespectacled parents who always work in the laboratory, take notes on new findings and read books [18]. A scientist can solve problems and find something new. The attitude drawn from the scientists towards solving problems and finding new discoveries can be used as a role model for students. For example, in learning physics students in class diligently take notes and are diligent in learning. Besides, when doing physics practicum, students can arrange tools properly in accordance with the procedure and diligently conduct experiments.

As for the adoption of scientific attitudes, students talk about the application of scientific behavior in studying physics. Scientific attitude is something done in solving problems, assessing ideas and information to make decisions in the form of an approach. There are 3 basic components found in scientific attitudes, namely feelings, beliefs and actions [19]. The three components can be applied using scientific methods or methods that can form an active attitude, have critical thinking, structure, and can be independent and logical. For example, when carrying out an experimental activity, the steps of a structured and clear experiment required students to look for more scientific information. Thus, the knowledge gained will be more conceptualized and proven true from the experimental hypotheses that students study.

Based on this, if students already have the attitude like a scientist and been scientific towards learning physics, then the next they will settle down and continue their career in the field of Physics as well. The desire for a career in physics means there is a belief that will continue to work in the world of physics. However, not many students are interested in physics because many people think that physics is a difficult subject so that work related to physics is certainly difficult. Many women don't like complicated things like physics. Usually male students prefer careers related to science, while female students prefer scientific activities [20]. The application of curriculum and technology used by teachers in teaching as well as the student environment that changes become a factor in the emergence of negative feelings towards physics. Submission of such information needs to be considered because if given scientific information not many students will receive the information well so that there are students who show positive attitudes and some who show negative attitudes. There is a lack of knowledge from the teacher regarding the weak attitude of students towards physics subjects exacerbates the circumstances in which students' negative attitudes towards physics will increase.

The purpose of this study was to determine the comparison of the attitudes of students towards learning physics at high schools in Jambi City and Batang Hari Regencies. The indicators used are the normality of scientists, adoption of scientific attitudes, and career interests in the field of physics. In this study the questions asked are:

1. What is the normality attitude of scientists towards physics?

2. What is the attitude of adoption of scientific attitudes towards physics?

3. How about a career interest in physics?

4. How do the physics attitudes compare at SMA Ferdy Ferry Kota Jambi and SMAN 6 Batang Hari?

\section{Materials and Methods}

Researchers used quantitative research designs with survey methods. Quantitative research methods are defined as methods used to examine populations or specific samples, using research instruments, quantitative or statistical data analysis that aims to test hypotheses that have been made [21]. According to ref [22] research a survey is quantitative research procedure in which the researcher administers survey of sample or in the entire, opinion, behavior, or specific characteristic of the population. The design of this study was applied because it was in accordance with the objectives of the study, namely to find out comparis on of student attitudes towards physics and the results of the student attitudes description by using indicators of scientist normality, scientific attitudes adoption and a career interest in physics at SMA Ferdy Ferry Putra Kota Jambi and SMAN 6 Batang Hari.

\subsection{Sample/ Working Group/Participants}

The subjects of this study were 281 students consisting of 125 students from SMA Ferdy Ferry Putra Kota Jambi and 156 students from SMAN 6 Batang Hari. The sampling technique used in this study was purposive sampling. Purposive sampling is a sample that is done by taking subjects rather than based on strata, randomly or regionally but based on the existence of certain goals [23]; [24]. 


\subsection{Data Collection Instruments/ Data Collection Methods/ Data Collection Techniques}

The instrument used a questionnaire adopted from ref [22]. This instrument used a Likert scale. The scale consists of 5 points with very agree value is 5 , agree is 4 , neutral is 3 , disagree is 2 , and very disagree is 1 . The focus of this research is on three dimensions of attitudes namely scientists normality, scientific attitudes adoption and career interest in physics (table 1) [22].

Table 1. Indicators Instrument Attitude Questionnaire

\begin{tabular}{|c|c|c|c|}
\hline \multirow{2}{*}{ Variable } & \multirow{2}{*}{ Indicators } & \multicolumn{2}{|c|}{ Statement Number } \\
\cline { 3 - 4 } & & + & - \\
\hline \multirow{4}{*}{ Attitude } & Scientists Normality & 9,30 & $2,16,23$ \\
\cline { 2 - 4 } & $\begin{array}{c}\text { Scientific attitudes } \\
\text { adoption }\end{array}$ & $4,11,25,37$ & $18,32,42$ \\
\cline { 2 - 4 } & $\begin{array}{c}\text { Career Interest in } \\
\text { Physics }\end{array}$ & $\begin{array}{c}7,21,35, \\
45,52\end{array}$ & $\begin{array}{c}14,28,40, \\
49,52\end{array}$ \\
\hline
\end{tabular}

The research procedure begins by following the procedures in stages. The questions are the stages of preparation, proposal, formulating the problem and the variables. Then a literature review was conducted, looking for a theory supporting the discussion of the problem under study in order to obtain an overview of the research to be carried out and the instruments needed. At the stage of data collection, the questionnaire was given to 281 students at SMA Ferdy Ferry Putra Kota Jambi and SMAN 6 Batang Hari. From the data, the data analysis is then done, which is filtering out the proper data and coding the data.

\subsection{Data Analysis}

Data analysis used is descriptive and inferential. Description of the amount of data including mean, mode, median, maximum and minimum is descriptive statistics [25]. Given that it is impossible to gather data from all members of the population, inferential statistics can allow researchers to generalize findings to other similar language learners; that is, to make inferences [11]. Inferential statistics use analysis with homogeneity tests, normal tests, intervals, and t-tests. The $\mathrm{T}$ test is a different test to find out if there is a significant difference in the average between the 2 free groups that scale the interval / ratio of data to the data source of different subjects. A researcher can use one-sample t-test to compare the mean of a sample with a hypothesized population mean to see if the sample is significantly different [26]. Data were analy zed using the SPSS 22 program to obtain the percentage, frequency and mean of the data.

\section{Results}

The novelty of this study is the attitude that is influenced by three indicators namely the normality of scientists, adoption of scientific attitudes and career interests in the field of physics. Attitudes related to coping with emotions that occur during the learning process take place, and they play an important role in shaping human behavior [3]. Scientist normality describes how students see scientists and position themselves as learners of science [3]. Adoption of scientific attitude measures students 'willingness and readiness to give scientific responses and students' openness to new information [3]. Career interest in both the natural sciences and physics is one of the indicators of attitude. Students who are not interested in a career in physics are usually driven by negative attitude factors [27].

\subsection{Scientists Normality}

The scientist's normality is one of a person's behavior that resembles a scientist whose view that scientists are normal people, does not accuse scientists of being quiet and unable to socialize so that they are kept away from the lives of the surrounding community. From the indicator of student scientists normality towards physics at SMA Ferdy Ferry Putra Kota Jambi and SMAN 6 Batang Hari, we can see the results of the questionnaire that has been distributed, such as table 2 . 
Table 2. Scientists Normality in Physics at SMA Ferdy Ferry Putra Kota Jambi and SMAN 6 Batang Hari

\begin{tabular}{|c|c|c|c|c|c|c|c|c|}
\hline \multicolumn{4}{|l|}{ Classification } & \multirow{2}{*}{ Mean } & \multirow{2}{*}{ Median } & \multirow{2}{*}{ Min } & \multirow{2}{*}{$\operatorname{Max}$} & \multirow{2}{*}{$\%$} \\
\hline School & Interval & Category & Total & & & & & \\
\hline \multirow{5}{*}{$\begin{array}{l}\text { SMA Ferdy Ferry } \\
\text { Putra Kota Jambi }\end{array}$} & $5.0-9.0$ & Very not good & 0 & \multirow{5}{*}{16} & \multirow{5}{*}{16} & \multirow{5}{*}{1} & \multirow{5}{*}{20} & 0.0 \\
\hline & $9.1-13.0$ & Not good & 6 & & & & & 4.8 \\
\hline & $13.1-17.0$ & Sufficient & 82 & & & & & 65.6 \\
\hline & $17.1-21.0$ & Good & 35 & & & & & 28.0 \\
\hline & $21.1-25.0$ & Very Good & 2 & & & & & 1.6 \\
\hline \multicolumn{3}{|l|}{ Total } & 125 & & & & & 100 \\
\hline \multirow{5}{*}{ SMAN 6 Batang Hari } & $5.0-9.0$ & Very not good & 0 & \multirow{5}{*}{16.41} & \multirow{5}{*}{17} & \multirow{5}{*}{1} & \multirow{5}{*}{21} & 0.0 \\
\hline & $9.1-13.0$ & Not good & 9 & & & & & 5.8 \\
\hline & $13.1-17.0$ & Sufficient & 69 & & & & & 44.2 \\
\hline & $17.1-21.0$ & Good & 70 & & & & & 44.9 \\
\hline & $21.1-25.0$ & Very Good & 8 & & & & & 5.1 \\
\hline \multicolumn{3}{|l|}{ Total } & 156 & & & & & 100 \\
\hline
\end{tabular}

In table 2, it can be described the attitude of student scientists normality at SMA Ferdy Ferry Putra Kota Jambi, is the most dominant being sufficient category with a percentage of $65.6 \%$. While the attitude of student scientists normality in SMAN 6 Batang Hari is the most dominant, namely good category with a percentage of $44.9 \%$.

Next are the results of interviews conducted by researchers based on indicators of scientist normality:

Question : Do you know about physics scientists?

Answer: yes, like Newton. Maybe his life is like the lives of people in general

Question : In your opinion, can a physics scientist have a happy family?

Answer : I don't know for sure, because as far as I know a scientist is like any other human.

Students who agree with it cannot place themselves like scientists with all kinds of lives and habits. The percentage in the not good category obtained from SMA Ferdy Ferry Putra Kota Jambi was caused by several factors, especially from the teaching teachers in the field of study. The teacher instilled the concept in students so that they did not assume that physics was a difficult lesson.
In contrast to SMAN 6 Batang Hari, most can imagine the daily life of scientists and assume that a scientist also has a normal life side like humans in general [28]. This shows that, students have the view that scientists are normal people, do not accuse scientists of being quiet and unable to socialize so that they are kept away from the lives of the surrounding community. This is confirmed by students starting to think of scientists as realistic people, inventors and problem solvers, doing many things, unique, working as thinkers [29]. Scientific normality assesses how students see scientists and place themselves as a scientist or scientist learner.

\subsection{Scientific Attitudes Adoption}

Scientific attitudes adoption is one behavior in which a student places himself like a scientist and acts scientifically with all kinds of life and habits. As for the scientific attitudes adoption toward physics at SMA Ferdy Ferry Putra Kota Jambi and SMAN 6 Batang Hari, look at the results of the questionnaire that has been distributed in table 3 . 
Table 3. Scientific Attitudes Adopstion in Physics at SMA Ferdy Ferry Putra Kota Jambi and SMAN 6 Batang Hari.

\begin{tabular}{|c|c|c|c|c|c|c|c|c|}
\hline \multicolumn{4}{|l|}{ Classification } & \multirow{2}{*}{ Mean } & \multirow{2}{*}{ Median } & \multirow{2}{*}{ Min } & \multirow{2}{*}{ Max } & \multirow{2}{*}{$\%$} \\
\hline School & Interval & Category & Total & & & & & \\
\hline \multirow{5}{*}{$\begin{array}{l}\text { SMA Ferdy Ferry } \\
\text { Putra Kota Jambi }\end{array}$} & $7.0-12.6$ & Very not good & 0 & \multirow{5}{*}{24.43} & \multirow{5}{*}{24} & \multirow{5}{*}{18} & \multirow{5}{*}{33} & 0.0 \\
\hline & $12.7-18.2$ & Not good & 1 & & & & & 0.8 \\
\hline & $18.3-23.8$ & Sufficient & 41 & & & & & 32.8 \\
\hline & $23.9-29.4$ & Good & 78 & & & & & 62.4 \\
\hline & $29.5-35.0$ & Very Good & 5 & & & & & 4.0 \\
\hline \multicolumn{3}{|l|}{ Total } & 125 & & & & & 100 \\
\hline \multirow{5}{*}{$\begin{array}{l}\text { SMAN } 6 \text { Batang } \\
\text { Hari }\end{array}$} & $7.0-12.6$ & Very not good & 0 & \multirow{5}{*}{26.45} & \multirow{5}{*}{26} & \multirow{5}{*}{17} & \multirow{5}{*}{35} & 0.0 \\
\hline & $12.7-18.2$ & Not good & 1 & & & & & 0.6 \\
\hline & $18.3-23.8$ & Sufficient & 27 & & & & & 17.3 \\
\hline & $23.9-29.4$ & Good & 100 & & & & & 64.1 \\
\hline & $29.5-35.0$ & Very Good & 28 & & & & & 17.9 \\
\hline \multicolumn{3}{|l|}{ Total } & 156 & & & & & 100 \\
\hline
\end{tabular}

In table 3 for the scientific attitudes student adoption at SMA Ferdy Ferry Putra Kota Jambi and SMAN 6 Batang Hari both have the most dominant percentage, namely good category with $62.4 \%$ and $64.1 \%$ respectively. In this case, students can put themselves in the same way as scientists and be scientific with all kinds of life and their habits in doing physics tasks in class. The attitude of students who like to ask after finding a solution shows that the curiosity of students is very great towards the investigation they are doing. This positive attitude can be owned by a scientist [3]; [30]; [31]. This can be seen at SMA Ferdy Ferry Putra Kota Jambi and SMAN 6 Batang Hari. The habit of students who are curious about new things will raise questions in the minds of students and make them find out about it [19]; [32]; [33]. From a form of appreciation in scientific inquiry, students show that they begin to gather evidence, think creatively, actively, think critically, and communicate a conclusion, because they face situations related to science [3]; [34].

The results of the questionnaire analys is in Table 3 with indicators of scientific attitudes student adoption at SMA Ferdy Ferry Putra Kota Jambi dominant showed good attitudes. The results of the interviews that have been conducted are the followings,

Question: "Do you like to find out about something new and why?"

Answer: "Yes, I like to find out new things that I have not asked for because they are fun and make me curious. My mind became more open, my knowledge also increased with new information"

The results of the interviews at SMAN 6 Batanghari that have been conducted are the followings.

Question: "Do you like to find out about something new and why?"

Answer: "What is certain is that I am a human who to get new information to add to my insights into my life.
For example, I studied physics. However, the level of strength in remembering new things also varies. But in physics, something like a new symbol in physics only lasts when I'm in the process of teaching and learning in class. The next day will most likely forget the meaning of the symbol. The teacher who explained it also didn't make me fully understand. When I found out it was also difficult to understand. Because of that, I don't really like physics"

The results of interviews conducted at SMA Ferdy Ferry Putra Kota Jambi and SMAN 6 Batanghari, show that students get many critical and scientific opinions to get the information they get. In addition there is also a high degree of curiosity and students also want to be open and accept the opinions of others. Students who have a high scientific attitude will have curiosity and also a high desire to find and create new things, be open, facilitate in teams, and be responsible for assignments [30]. Students' habits about new things will raise many questions and critical attitude of students and make them find out for themselves about it. The attitude of science will encourage students 'willingness to ask questions in students' thinking and increase enthusiasm about finding answers to problems [34]. The attitude of science will encourage students to ask questions in students' thinking and increase enthusiasmabout finding answers to questions [35]; [36].

Students have high curiosity and accept opinions from others. Students who have a high scientific attitude will also have a high desire to discover and create new things, be open, cooperate in teams, and be responsible for assignments [37]. Students' habits about new things will raise many questions and critical attitude of students and make them find out for themselves about it. The attitude of science will encourage students 'willingness to ask questions in students' thinking and increase enthusiasm about finding answers to problems [38]. 
Table 4. Career Interest in Physics at SMA Ferdy Ferry Putra Kota Jambi and SMAN 6 Batang Hari

\begin{tabular}{|c|c|c|c|c|c|c|c|c|}
\hline \multicolumn{4}{|l|}{ Classification } & \multirow{2}{*}{ Mean } & \multirow{2}{*}{ Median } & \multirow{2}{*}{ Min } & \multirow{2}{*}{$\operatorname{Max}$} & \multirow{2}{*}{$\%$} \\
\hline School & Interval & Category & Total & & & & & \\
\hline \multirow{5}{*}{$\begin{array}{l}\text { SMA Ferdy Ferry Putra } \\
\text { Kota Jambi }\end{array}$} & $10.0-18.0$ & Very not good & 0 & \multirow{5}{*}{29.21} & \multirow{5}{*}{30} & \multirow{5}{*}{20} & \multirow{5}{*}{38} & 0.0 \\
\hline & $18.1-26.0$ & Not good & 29 & & & & & 23.2 \\
\hline & $26.1-34.0$ & Sufficient & 85 & & & & & 68.0 \\
\hline & $34.1-42.0$ & Good & 11 & & & & & 8.8 \\
\hline & $42.1-50.0$ & Very Good & 0 & & & & & 0.0 \\
\hline \multicolumn{3}{|l|}{ Total } & 125 & & & & & 100 \\
\hline \multirow{5}{*}{ SMAN 6 Batang Hari } & $10.0-18.0$ & Very not good & 1 & \multirow{5}{*}{31.56} & \multirow{5}{*}{31} & \multirow{5}{*}{13} & \multirow{5}{*}{49} & 0.6 \\
\hline & $18.1-26.0$ & Not good & 15 & & & & & 9.6 \\
\hline & $26.1-34.0$ & Sufficient & 103 & & & & & 66.0 \\
\hline & $34.1-42.0$ & Good & 35 & & & & & 22.4 \\
\hline & $42.1-50.0$ & Very Good & 2 & & & & & 1.3 \\
\hline \multicolumn{3}{|l|}{ Total } & 156 & & & & & 100 \\
\hline
\end{tabular}

\subsection{A career Interest in Physics}

A career interest in physics is a desire to continue studies in physics. The results of the questionnaire that have been disseminated and processed about career interest in physics at SMA Ferdy Ferry Putra Kota Jambi and SMAN 6 Batang Hari can be seen in table 4.

In table 4 a career interest in physics at SMA Ferdy Ferry Putra Kota Jambi and SMAN 6 Batang also had the same dominant percentage, namely sufficient category with $68 \%$ and $66 \%$ respectively. Students who can appreciate the role of physics in daily life are only students who have performed well in high school physics, are talented in science, and are very good in mathematics [39]. The great impact of students' attitudes and behavior is influenced by interests. Therefore, interest plays an important role in student life [3]. Based on this, if students already have an attitude like a scientist and are scientific about learning physics, then students will then settle down and continue their careers in physics as well [3]; [40]; [41]. Because, if students want a career in physics must also pay attention to students' interest in the subject itself because interest is very influential on the achievement of a student's career and personal life [42]; [43]. Dominant male students prefer the path of science as a career and scientific activity [44]. However, from the good category at SMA Ferdy Ferry Putra Kota Jambi and SMAN 6 Batang Hari, the percentage is quite far at $6.9 \%$. In this case, most students in SMAN 6 Batang hari want to continue their studies in the field of physics compared with SMA Ferdy Ferry Putra Kota Jambi.

The results of the questionnaire data analysis in table 4 with indicators of career interest in physics at SMA Ferdy Ferry Putra Kota Jambi showed that the dominant students were in the sufficient category. The results of the interviews that have been conducted are the followings..

Question: "How do you feel when doing experiments?
Explain the reason"

Answer: "I like doing experiments. By doing experiments, physics lessons are not boring and quite interesting and strengthen teamwork. I also became aware of the application of physical laws"

Question: "If you have trouble finding answers or certain things during your experiment, would you rather find your own answers than ask a friend?"

Answer: "If I still can, I prefer to find out by myselfand read the book. But if I don't know, I just ask my teacher or friend. But that is only sometimes. If it is indeed difficult and not very important. I leave it"

The results of the interviews at SMAN 6 Batanghari that have been conducted are the followings.

Question: "Have you ever thought about continuing your career in physics? Explain the reason!"

Answer: "Sometimes I think about wanting to continue their studies in physics. But that is not a priority. Because I thought my life would be complicated by being faced with physical formulas and having to do certain experiments about physics. But if I choose to study or experiment. I will choose to experiment and the career that I will choose is also not in terms of education."

Question: "If you have trouble finding answers or certain things during the experiment, would you rather find your own answers than ask a friend?"

Answer: "As for physics, I still really need help from others such as teachers, friends and others. In addition, physics must ask me and other students to think extra and of course the abilities of students are different"

The results of the interviews conducted at SMA Ferdy Ferry Putra Kota Jambi and SMAN 6 Batanghari, found that a career or continuing a career in physics is not a priority. Because students assume that when they have 
entered the world of physics, their lives will become complicated. However, students like to do experiments. Even if he chooses a career in physics, then he will choose to deal with laboratories in comparison with education. Many in physics present abstract concepts, and sometimes these things hinder students' enjoyment of physics [45]. By conducting experiments, learning abstract of physics becomes easier for students to understand. So that many students who prefer experiment or practicum to just studying physics material. This practicu m will create good teamwork and will increase student confidence in what he has been able to. Students' confidence in their ability to learn physics determines their involvement in continuing their career in physics [5]; [46].

Based on this, if students already have the attitude like a scientist and behave scientifically towards learning physics, next student will stay and continue his career in physics as well [33]; [47]; [48]. Students 'desires for physics greatly affect career achievement in students' personal lives [29]. However, students must also know their liking for the lesson itself because of the love for something that will determine itself in the future [41]; [49]. Because, the deeper he studies physics the desire for a career in physics will also increase. In this case, only a few students at SMA Ferdy Ferry Putra Kota Jambi and SMAN 6 Batanghari want to continue their studies in physics.

\subsection{Result on Normality and Homogeneity Test}

Based on the statistical analysis of two data, namely SMA Ferdy Ferry Putra Kota Jambi and SMAN 6 Batang Hari regarding the attitudes of students in physics, from table 5, the data on attitudes of physics students in both schools is normally distributed. This can be seen in the value of sig $>0.05$, so it is said to be normally distributed.

Then the results of statistical analysis of student attitudes in physics show that the data is homogeneous. This is indicated by the value of sig $>0.05$ in table 5 . If the sig value is greater than 0.05 , then the data is said to be homogeneous and a comparison test will be conducted to see whether there are differences in attitudes of students at SMA Ferdy Ferry Putra Kota Jambi and SMAN 6 Batang Hari.

\subsection{Result on T-Test}

From the results of the statistical analysis to see the comparison of the two high schools with the T-test, there is a difference between SMA Ferdy Ferry Putra Kota Jambi and SMAN 6 Batang Hari. This is shown in table 6, where is Sig. (2-tailed) $<0.05$. So that the attitudes of students in physics in these two schools are said to be different.

Tabel 5. Normality and Homogeneity Test of Students' Attitudes towards Physics at SMAFerdy Ferry Putra Kota Jambi and SMAN 6 Batang Hari

\begin{tabular}{|c|c|c|c|c|c|c|}
\hline & & malit & & \multirow{2}{*}{\multicolumn{3}{|c|}{ Homogeneity }} \\
\hline & \multicolumn{3}{|c|}{ Kolmogorov- Smirnova } & & & \\
\hline & Statistic & Df & Sig. & f1 & f2 & Sig. \\
\hline $\begin{array}{c}\text { SMA Ferdy Ferry Putra } \\
\text { Kota Jambi }\end{array}$ & .075 & 125 & $.200^{*}$ & \multirow{2}{*}{1} & \multirow{2}{*}{279} & \multirow{2}{*}{.065} \\
\hline SMAN 6 Batang Hari & .065 & 156 & .055 & & & \\
\hline
\end{tabular}

Tabel 6. T-Test of Students' Attitudes towards Physics at SMA Ferdy Ferry Putra Kota Jambi and SMAN 6 Batang Hari

\begin{tabular}{|c|c|c|c|c|}
\hline \multirow{2}{*}{} & \multicolumn{3}{|c|}{ t-test for Equality of Means } \\
\cline { 3 - 5 } & Sig. (2-tailed) & Mean Difference & Std Error Difference \\
\hline \multirow{3}{*}{ Attitudes } & Equal variances assumed & .000 & -11.05643 & 1.24149 \\
\cline { 2 - 5 } & Equal variance not & .000 & -13.04744 & 1.51086 \\
\hline
\end{tabular}


The results of Test $\mathrm{T}$ obtained Sig (2-tailed) be low 0.05 or equal to 0,000 . It can be seen that there is a significant difference between students' attitudes in physics at Ferdy Ferry Putra Kota Jambi and 6 Batang Hari High Schools. We know the difference from observations when distributing questionnaires about students' attitudes towards physics in both schools. Students who like physics will show a positive attitude towards physics, which is shown by never arriving late, always doing physics assignments on time and so on. A positive attitude will make students more positive in all activities [50]. Likewise, if students have a positive attitude towards their subjects they will do the same positive things and see their learning.

Another difference can be seen from the students' answers about attitude statements, where students do not mean to learn physics, because many students do not repeat physics lessons at home. This causes student physics learning outcomes to be low because of the factors of the students themselves. According to ref [51] said that although teachers and learning facilities are good, students do not show a serious attitude towards learning, and good results will still not be achieved. Student seriousness can be obtained from himself, even though there are qualified teaching staff and facilities.

The positive attitude shown by students will affect the subjects they learn such as diligently doing assignments, adding insight by searching for the material that has been learned so that it will get the desired achievement, and vice versa in students who show negative attitudes towards a subject will have an impact on the lessons themselves like being lazy, which will affect their future. If the teacher only uses one method that will allow students to show negative attitudes in the learning process, students will get non-optimal learning outcomes. Because the use of media or other facilities will help students reduce their dislike of Physics. Individual learning at home is one of the optimal learning processes if done well and seriously in order to achieve satisfactory results.

Based on the results above, we can know that students who like physics will show a positive attitude towards physics, by contrast students who don't like physics will show a negative attitude towards physics. We can discuss SMA Ferdy Ferry Putra Kota Jambi and SMAN 6 Batang Hari in different schools that show different attitudes in physics. So the physics teacher has demanded that students show a positive and active attitude when learning physics which in turn gets good learning outcomes.

\section{Conclusions}

Based on the results of the analysis obtained, the attitudes of students in each indicator at SMA Ferdy Ferry Putra Kota Jambi and SMAN 6 Batang Hari have different categories, this is caused by many factors, especially from the teaching teachers in the field of study, how do teachers embed concepts to students so they do not have the notion that physics is a difficult lesson. In addition, students who have a scientific attitude towards learning physics are not necessarily interested in furthering a career in physics. From the two data, it also appears that students are not too willing to pursue a career in physics like being a scientist, working in a laboratory, being a teacher or lecturer in physics, and so on. In addition, their assumption that at a higher level of education physics lessons are increasingly difficult and to achieve career goals in physics requires a reasonable amount of time.

\section{REFERENCES}

[1] Darmaji, Astalini, D. A. Kurniawan, R. Perdana, D. S. Putra, "A study relationship attitude toward physics, motivation, and character discipline students senior high school, in Indonesia" International Journal of Learning and Teaching, Vol. 11, no. 3, pp. 99-109. 2019

[2] Astalini, D. A. Kurniawan, N. Kurniawan, \& L. Anggraini, "Evaluation of student's attitude toward science in Indonesia". Open Journal for Educational Research (OJER), vol. 3, no. 1, pp. 1-12, 2019

[3] Astalini, D. A. Kurniawan, Darmaji, L. R. Sholihah, \& R. Perdana. "Characteristics of students' attitude to physics in Muaro Jambi high school" Humanities \& Social Sciences Reviews (HSSR), vol. 7, no. 2, pp. 91-99, 2019

[4] H. Guzel. "The relationship between students' success in physics lessons and their attitude towards mathematics" Turkish Science Education, vol. 1, no. 1, pp.28-29, 2004

[5] Astalini, D. A. Kurniawan, D. K. Sari, \& W. Kurniawan "Description of scientific normality, attitudes of investigation and interested career on phy sics in senior high school". JIPF (Jurnal Ilmu Pendidikan Fisika), vol. 4, no. 2, pp. 56-63, 2019

[6] Astalini, Darmaji, H. Pathoni, W. Kurniawan, Jufrida, D. A. Kurniawan, Perdana, R. Motivation and attitude of students on physics subject in the middle school in Indonesia. International Education Studies (IES) Journal, 12(9), 15-26. 2019

[7] A. H. Eagly, \& Chaiken, S. "The psychology of attitudes" Harcourt Brace Jovanovich College Publishers. 1993

[8] S. O. Akinoso. "Students attitude to mathematics as correlates to attitude and performance in chemistry". The Eurasia Proceedings of Educational \& Social Sciences, vol. 8, no. 1, pp. 40-45, 2017

[9] H. Kaya, \& U. Boyuk. "Attitude towards physics lessons and physical experiments of the high school students". European journal of physics education, vol. 2, no. 1, pp. 23-31, 2011

[10] A. Veloo, R. Nor, \& R. Khalid. "Attitude towards physics and additional mathematics achievement". International Education Studies, vol. 8, no. 3, pp.35-43, 2015 
[11] N. Demirtaşli, S. Yalcin, \& Cansu. "The development of IRT based attitude scale towards educational measurement course* ölçme ve değerlendirme dersine yönelik tutum ölçeğinin madde tepki kuramına dayalı olarak geliştirilmesi". Journal of Measurement and Evaluation in Education and Psychology, vol. 7, no. 1, pp. 133-144, 2016

[12] H. Boz, \& M. Çalışkan. "Developing an attitude observation form towards mathematics". Research on Education and Psychology, vol. 2, no. 1, pp.95-110, 2018

[13] N. Erdemir. "Determining students' attitude towards phy sics through problem-solving strategy". Asia-Pacific Forum on Science Learning and Teaching, vol. 10, no. 2, pp. 1-19, 2009

[14] M. K. Rosli, S. M. Maat, \& N. Rosli. "Students' attitude and anxiety towards statistics a descriptive analysis. Research on Education and Psychology, 1(1), 47-56. 2017

[15] Çener, E., Acun, İ., \& Demirhan, G. The impact of ICT on pupils' achievement and attitudes in social studies". Journal of Social Studies Education Research, vol. 6, no. 1, pp. 190-207, 2015

[16] V. Christidou. "Interest attitudes and images related to science: combining students' voices with the voices of school science, teachers, and popular science". International Journal of Environmental and Science Education, vol. 6, no. 2, pp. 141-159, 2011

[17] R. Mukhopadhyay. "Scientific attitude-some psychometric considerations". IOSR Journal Of Humanities And Social Science (IOSR-JHSS), vol. 19, no. 1, pp. 98-100, 2014

[18] E. Bang, \& D. R. Baker."'Gender differences in Korean high school students' science achiev ements and attitudes towards science in three different school settings". Online Submission, vol. 3, no. 2, pp. 27-42, 2013

[19] Sugiyono. "Metode Penelitian Kombinasi (Mixed Methods)". Alfabeta. 2018

[20] John. W. Creswell. "Educational Research Planning, Conducting and evaluating quantitative dan qualitative research.” University of Nebraska, 2015

[21] J. Heridiansyah. "Pengaruh Advertising Terhadap Pembentukan Brand Awareness Serta Dampaknya Pada Keputusan Pembelian Produk Kecap Pedas ABC (Studi Kasus Pada Konsumen Pengguna Kecap Pedas ABC di Kota Semarang)". Jurnal Stie Semarang. Vol 4, No 2, ISSN: 2252-7826, 2012

[22] R. Darmawangsa. "Pengembangan instrumen sikap siswa sekolah menengah atas terhadap mata pelajaran fisika", Jurnal Pendidikan Fisika-Journal of Phy sics Education, vol. 6, no. 1, pp. 107-114, 2018

[23] A. Mackey and S. M. Gass. "Second Language Research Methodology And Design.” Lawrence Erlbaum Associates, 2005

[24] B. Gerald. "A Brief Review of Independent, Dependent and One Sample." Vol. 4, no. 2, pp. 50-54, 2018 https://doi.org/10.11648/j.ijamtp.20180402.13

[25] L. Cohen, L. Manion, \& K. Morrison. "Research Methods In Education" Routlege, 2007

[26] Astalini, D. A. Kurniawan, \& L. Z. Nurfarida. "Deskripsi sikap siswa SMA di Batanghari berdasarkan indikator normalitas ilmuwan, adopsi dari sikap ilmiah , ketertarikan memperbanyak waktu, dan ketertarikan berkarir di bidang fisika," JRKPF UAD. vol. 5, no. 2, pp. 73-80, 2018 https://doi.org/10.12928/jrkpf.v5i2.10736

[27] M. D. Balçın, \& A. Ergün. "Secondary school students' perceptions and attitudes about scientists". European Journal of Education Studies, vol. 4, no. 4, pp.66-93, 2018

[28] D. A. Kurniawan, R. Perdana \& D. Kurniasari. "Identification of student attitudes toward physics learning at Batanghari district high school". The Educational Review USA, vol. 2, no. 9, pp. 475-484, 2018

[29] Astalini, D. A. Kurniawan, \& L. Anggraini. "Correlation between confidence with attitude toward science in secondary school in Indonesia". Beder Scientific Journal of Education Sciences (BJES), vol. 20, no. 1, pp. 30-45, 2019

[30] Erdogan, S. C. Science teaching attitudes and scientific attitudes of pre-service teachers of gifted students. Journal of Education and Practice, 8(6), 164-170. 2017

[31] Maison, M., Darmaji, D., Astalini, A., Kurniawan, D, A., \& Indrawati, $\mathrm{P}, \mathrm{S}$. Science process skills and motivation. Humanities \& Social Sciences Reviews (HSSR), 7(5), 48-56. 2019

[32] Bybee, R., McCrae, B., \& Laurie, R. PISA 2006: An assessment of scientific literacy. Journal of Research in Science Teaching: The Official Journal of the National Association for Research in Science Teaching. 46(8), 865-883. 2009

[33] Astalini, A., Darmaji D., Kurniawan, D. A., \& Destianti, A. Description of the dimensions attitudes towards science in junior high school at Muaro Jambi. International Journal of Sciences: Basic and Applied Research (IJSBAR), 47(1), 1-11. 2019

[34] Maison, M., Darmaji, D., Astalini, A., Kurniawan, D, A., \& Indrawati, P, S. Science process skills and motivation. Humanities \& Social Sciences Reviews (HSSR), 7(5), 48-56. 2019

[35] Rosdianto, H. (2017). Penentuan Percepatan Gravitasi pada Percobaan Gerak Jatuh Bebas dengan Memanfaatkan Rangkaian Relai. Spektra: Jurnal Fisika dan Aplikasinya, 2(2), 107-112.

[36] Guido, R. M. Attitude and motivation towards learning physics. International Journal of Engineering Research \& Technology, 2(11), 2087-2094. 2013

[37] D. A. Kurniawan \& Susanti, A. Attitudes of college students on the subject of mathematical physics iii in physics education program of Jambi University. The Educational Review USA, 2(11), 505-513. 2018

[38] Juan, A. R. Does it matter whether students enjoy learning science? exploring student attitudes towards science, south africa. Human Sciences Reseach Council, 1(1), 1-6. 2016

[39] Welch, A. G. Using the TOSRA to assess high school students' attitudes toward science after competing in the first robotics competition: an exploratory stud. Eurasia Journal of Mathematics, Science \& Technology Education, 6(3), 187-197. 2010

[40] İzzet Kurbanoğlu, N., \& Arslan, S. High school students' 
educational and career interest (science-technologymathematics) and career adaptabilities. Australian Journal of Career Development, 24(3), 166-172. 2015

[41] Bang, E., \& Baker, D. R. Gender differences in Korean high school students' science achievements and attitudes towards science in three different school settings. Online Submission, 3(2), 27-42. 2013

[42] Erdemir, N. Determining students' attitude towards physics through problem-solving strategy. Asia-Pacific Forum on Science Learning and Teaching, 10(2), 1-19. 2009

[43] Civelek, T., Ucar, E., \& Ustunel, H. (2014). Effects of a haptic augmented simulation on K-12 students'achievement and their attitudes towards physics. Eurasia Journal of Mathematics, Science \& Technology Education, 10(6), 565-574.

[44] Stefan, M., \& Ciomos, F. (2010). The 8th and 9th grades students' attitude towards teaching and learning physics. Acta Didactica Napocensia, 3(3), 7-14.

[45] Hardiy anti, K., Astalini, A., \& Kurniawan, D. A. (2018). Sikap siswa terhadap mata pelajaran fisika di Sma Negeri 5 Muaro Jambi. EduFisika, 3(2), 1-12.

[46] Nasrodin, N., Hindarto, N., \& Supeni, S. E. (2013). Analisis kebiasaan belajar ilmiah mahasiswa fisika pada pembelajaran mata kuliah praktikum fisika dasar. Unnes Phy sics Educational Journal. 2(1), 84-91.

[47] Ediansy ah, E., Kurniawan, D, A., Salamah, S., \& Perdana, R. (2019). Investigation of problem based learning: Process of understanding the concepts and independence learning on research statistics subject, Humanities \& Social Sciences Reviews (HSSR), 7(5), 1-11.

[48] Astalini, D. A. Kurniawan, D. K. Sari, \& W. Kurniawan "Description of scientific normality, attitudes of investigation and interested career on phy sics in senior high school”. JIPF (Jurnal Ilmu Pendidikan Fisika), vol. 4, no. 2, pp. 56-63, 2019

[49] Astalini, D. A. Kurniawan, D. K. Sari, \& W. Kurniawan "Description of scientific normality, attitudes of investigation and interested career on phy sics in senior high school”. JIPF (Jurnal Ilmu Pendidikan Fisika), vol. 4, no. 2, pp. 56-63, 2019

[50] Asrial, A., Syahrial, S., Kurniawan, D, A., Chan, F., Nugoroho, P., Pratama, R, A., \& Septiasari, R. Identification: The effect of mathematical competence on pedagogic competency of prospective teacher, Humanities \& Social Sciences Reviews (HSSR), 7(4), 85-92. 2019

[51] Darmaji, D., Kurniawan, D. A., \& Sury ani, A. Effectiveness of basic physics ii practicum guidelines based on science process skills. JIPF (Jurnal Ilmu Pendidikan Fisika), 4(1), 1-7. 2019 